\title{
ONE OF THE SMALLEST DIGGER IVASPS.
}

\author{
BY HENRY L. VIERECK, PHILADELPHIA, PA.
}

Ammoplanus ceanothae n. sp.

9 $2.5 \mathrm{~mm}$. Submarginal cell without a stump of a vein, as in Ammoplanus columbianus.

Clypeus convex, smooth, slightly rounded out on the anterior margin; front shining. very finely sculptured, bearing no impression; anterior ocellus about on a line with the posterior margin of the eve, distance between the posterior ocelli less than the distance between them and the nearest eye margin; pedicellum nearly as long as the first two joints of the flagellum, joints of the flagellum subequal ; pronotum smooth with no sha:p margins; dorsulum sculptured much like the front, in addition it has some sparse rather distinct fine punctures; mesopleurae sculptured like the dorsulum; metathorax dull granular, flat, with two longitudinal raised lines fairly close together; abdomen shining, apparently impunctate; pubescence pale, inconspicuous.

Black; antennae and legs testaceous, partly brown; mandibles, clypeus and tegulae brown.

Type locality, Lehigh Gap, Pennsylvania, where it was taken I7 July, I899, Ir, I2 July, 1900, and 29 June, 1901; on the latter date it was caught on the flowers of Ceanothus americanus, $L$.

Type Acad. Nat. Sci., Phila.

\section{A NEW SPECIES OF ROACH OF THE GENUS KAKERLAC (LOBOPTERA AUCT.) FROM SOUTHERN TEXAS.}

BY JAMES A. G. REHN, PHILADELPHIA, PA.

Recently Mr. C. Schaeffer, of the Brooklyn Institute of Arts and Sciences, submitted to the author for determination a single specimen of a species of the genus Kakerlac (Loboptera of authors). On comparison with the figures and descriptions of the previously known species of the genus it appears to be new.

Kakerlac schaefferi n. sp.

Type: ९; Esperanza Ranch, Brownsville, Cameron Co., Texas. (C. Schaeffer). Brooklyn Institute of Arts and Sciences.

Allied to $K$. americana (Scudder) ${ }^{1}$ and $K$. annulicornis (Saussure and Zehntner), ${ }^{2}$ but differing from the former in the more compressed anterior portion of the body, the narrower tegmina and the more arcuate pronotum; from annuli-

1Proc. Davenport Acad. Nat. Sci., VIII, p. 93. 'Biol. Cent. Amer., Orth., I, p.5t. 

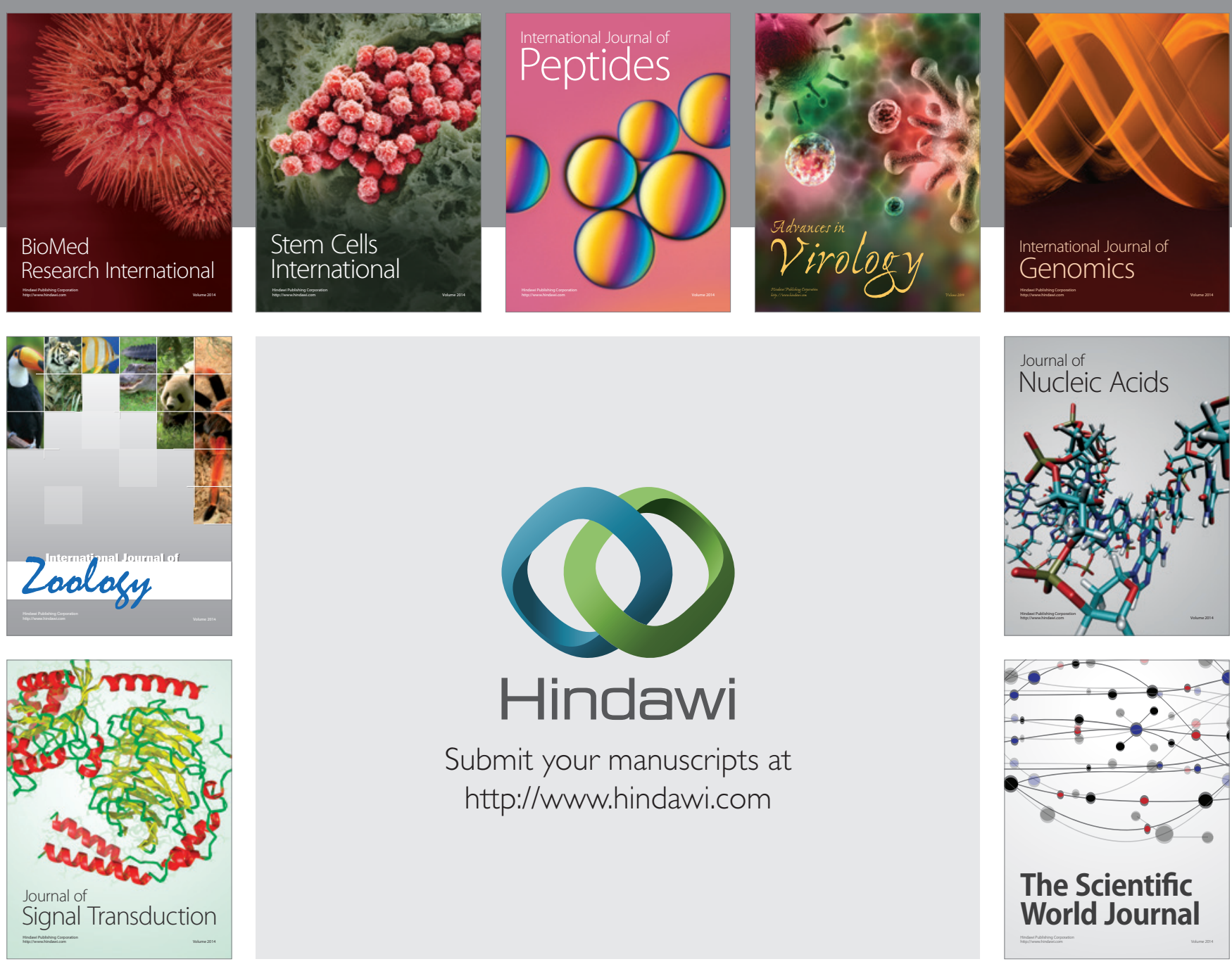

Submit your manuscripts at

http://www.hindawi.com
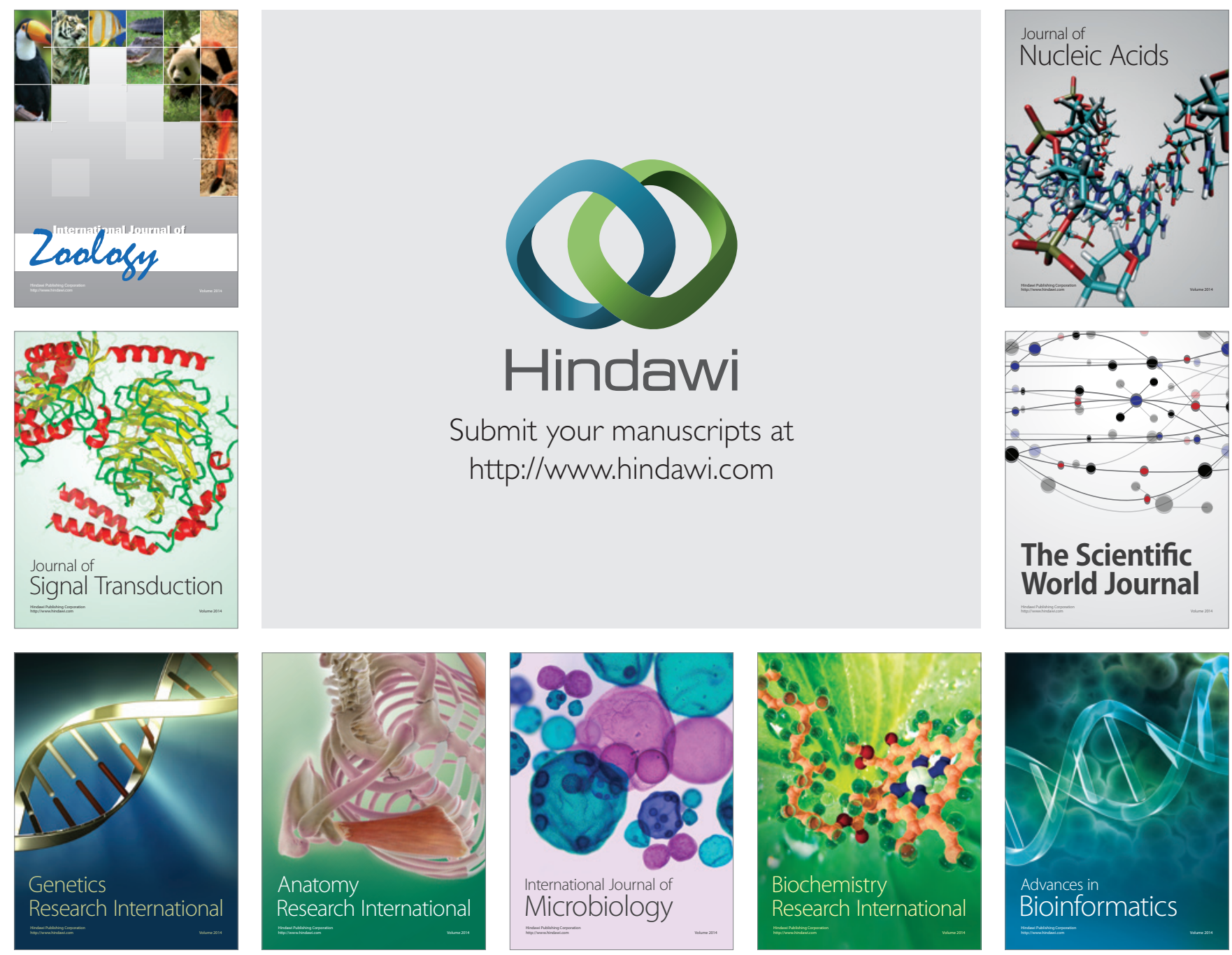

The Scientific World Journal
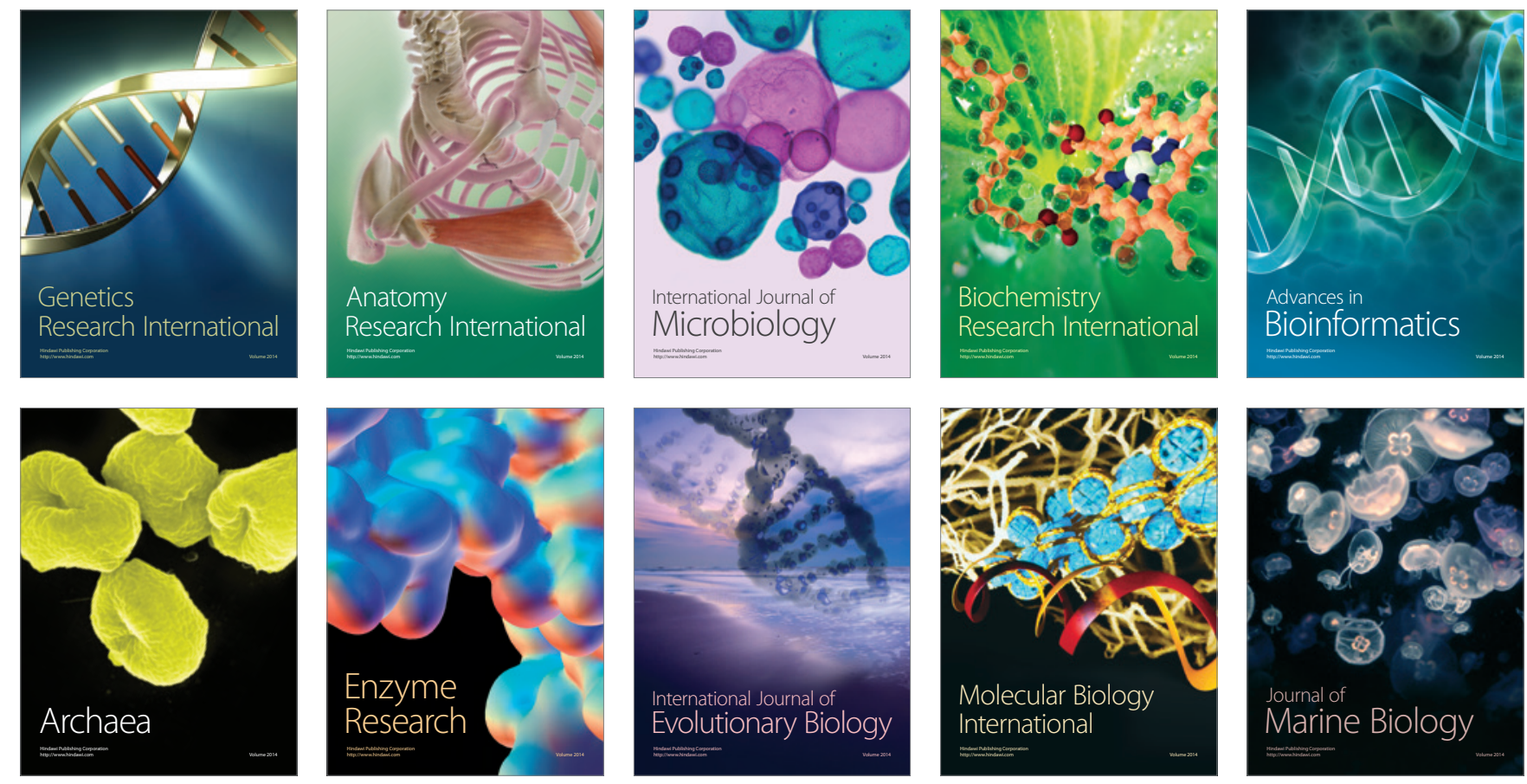